\title{
АНТИКОЛОНІАЛЬНЕ (ПРОТИМОСКОВСЬКЕ) СПРЯМУВАННЯ ІСТОРИЧНОЇ ДРАМИ «МИЛОСТЬ БОЖІЯ...» НЕВІДОМОГО АВТОРА
}

У статті розглядаються особливості започаткування і розвитку проблемного змісту та ідей опору московській колоніальній системі у першій половині ХVІІІ століття. Драматичний твір присвячено 80-річчю перемоги в Національно-Визвольній війні під проводом гетьмана Б. Хмельницького. Сюжет драми розгортається згідно $з$ ї̈ хронологією. Автор опирається на козацьку літописну спадщиину, представлену козацькими літописами Самовидия і Г. Граб'янки, а також національним фольклором (думи, історичні пісні та вірші про Б. Хмельницького).

У змісті історичної драми аналіз суспільних подій середини XVII століття у житті намої нації співвідноситься з колоніальним становищем Украӥни сьогодення автора - 20-ми роками ХVІІІ століття, щзо дозволяє обтрунтувати проблемно-ідейний зміст твору на двох сюжетних лініях - розкриття подій Національно-Визвольної війни і показ колоніального становщща нашого народу у другій половині XVII - першій половині XVIII столітmя.

Антиколоніальний дискурс на сторінках барокової драми розкривається через аналіз образу гетьмана Б. Хмельницького, збірних козаџьких образів, а також діючих персоніфікованих символічних образів - Украина, Вість, Смотргніе, Дгти украинскія і Писарь. Особливу увагу приділено згадиі про гетьмана Данила Апостола, який, на думку автора, мав стати другим Хмельнищьким, щчо звільнить рідну землю від імперської колоніальної системи. Невідомий автор наділяє образ Данила Апостола рисами національного визволителя XVIII століття. Завуальовано ведеться розповідь про двох російських імператорів, які ототожнюються з біблійним «каменем спотикання» для нашого народу на шляху до ідентичності та незалежності.

Втілення барокових постулатів (релігійність, символізм, алегоричність і парадоксальні поєднання) створено y змісті історичного драматичного твору для формування текстуально завуальованих антиколоніальних ідей проти Російської імперї у 20-х роках ХVIII століття. Висвітлюється вплив історичного драматичного твору на тогочасну авторську дійсність, в основі якої закладалися ідеї формування світогляду для антиколоніального супротиву в національній літературі подальших віків.

Ключові слова: колоніальна система, історична драма, икільна драма, антиколоніальний супротив, бароко, персоніфікація.

Yuliya VELYCHKOVSKA, orcid.org/0000-0003-4560-6447

Graduate Student at the Department of Ukrainian and Foreign Literature and Teaching Methods Hryhoriy Skovoroda University in Pereyaslav (Pereiaslav, Kyiv region, Ukraine) y.velychkovska@ukr.net

\section{ANTICOLONIAL (ANTI-MOSCOW) DIRECTION OF THE HISTORICAL DRAMA “GOD'S MERCY ...” BY AN UNKNOWN AUTHOR}

The article deals the specifics of origin and development of problematic content and ideas of resistance to the Moscow colonial system in the first half of the XVIII century, which embodied in the historical drama "God's Mercy ..." by an unknown author. The dramatic work was dedicated to the 80th anniversary of the victory in the National Liberation War led by Hetman B. Khmelnitsky. The plot of the drama is develops according to its chronology. The author relied to the Cossack chronicles (the chronicles of Samovidets and G. Hrabianka) and national folklore (thoughts, historical songs and poems about B. Khmelnytsky).

In the context of historical drama, the analysis of the social events of the middle of the seventeenth century in the life of our nation correlates with the colonial situation of Ukraine of the author's present - the 20s of the XVIII century, that allows to substantiate the problematic and ideological content of the work on two story lines - revealing the events of the National Liberation War and showing the colonial position of our people in the second half of the XVII-first half of the XVIII centuries. 
On the pages of the baroque drama the anticolonial discourse is revealing through the analysis of the image of Hetman B. Khmelnytsky, the collective Cossack images, as well as the acting personalized symbolic images - Ukraine, Vist, Smotrniye, Ukrainian children and Clerk. Particular attention is paid to the mention of Hetman Daniel Apostle, who according to the author, should become the second Khmelnytsky, that would liberate his native land from the imperial colonial system. An unknown author endows the Daniel Apostle's image with the features of the national liberator of the XVIII century.

The story of two Russian emperors who is identify with the biblical "stumbling block" for our people on the path to identity and independence is being veiled. The embodiment of baroque postulates, such as religiosity, symbolism, allegoricality and paradoxical combinations, was created in the content of historical dramatic work for the formation of textually veiled anticolonial ideas against the Russian Empire in the 20s of the 18th century. The impact of historical dramatic work on contemporary authorial reality, at the heart of which the idea was creating of forming an outlook for anti-colonial resistance in the national literature of later ages, is highlighting.

Key words: colonial system, historical drama, school drama, anti-colonial resistance, baroque, personification.

Постановка проблеми. Драматичний твір «Милость Божія, Украину оть неудобъ носимыхъ обидъ лядскихъ чрезъ Богдана Зиновія Хмельницкаго преславного войскъ запорозскихъ гетмана, свободившая, и дарованными ему надъ ляхами побъдами возвеличившая, на незабвенную толикихъ его щедроть память репрезентованная въ школахъ Кіевскихъ 1728 льта», присвячений 80-річчю з початку Національно-Визвольної війни під проводом Б. Хмельницького, увійшов у національну літературу XVIII століття в часи розгортання колоніальної політики Російської імпеpiї на Україні (руйнування Батурина, зменшення освітньої ролі Києво-Могилянської академії, ліквідація гетьманства, підкупи московськими чинами козацької старшини), що позначилося на ідейно-проблемному змісті твору. Це один із перших драматичних творів, який торкнувся колоніальної проблематики.

У 1857 році М. Максимович в «Русской Бесъдъ» у статті «Воспоминаніе о Богдань Хмельницкомъ» вперше опублікував здогад про автора драматичного твору, віддаючи перевагу професору-класицисту Феофанові Прокоповичу. Автор статті опирався на схожість художнього стилю історичних драм «Володимира» митця та «Милості Божої». О. Бодянський як перший видавець драми «Милость Божія...» у збірнику наукових праць «Чтенія въ Императорскомъ обществђ исторіи и древностей россійскихъ» (1858 рік) із коментарем М. Максимовича не погодився та закликав інтелігенцію вирішити питання «<..> точно ли драма эта принадлежить перу знаменитаго іерарха, или же она произведеніе другого $<\ldots>>$ (Милость Божія, 1858: 78), сповнене патріотизмом та антиімперськими поглядами автора.

Аналіз досліджень. Тривалий час авторство приписували то професору Києво-Могилянської академії Феофану Прокоповичу, то викладачам поетики і риторики - Інокентію Неруновичу чи Феофану Трохимовичу (Історія української літератури, 2014, Т. 2: 533). Розв'язанням цієї про- блеми займалися П. Житецький, М. Петров, I. Франко, М. Возняк, О. Білецький, М. Тихонравов, М. Наєнко, В. Шевчук та інші.

Змістові ідеї твору, які були закладені патріотично свідомим українцем, прихильним до політики мазепинця Д. Апостола, висвітлені у працях С. Єфремова, Л. Онишкевича, М. Наєнко, В. Шевчук, М. Сулими, П. Білоуса. Однак аналіз ідейнопроблемного змісту драматичного твору залишив поза увагою викриття антиімперського змісту драми, яка 3 огляду на історичні умови є завуальованим складником «Милості Божої...».

Мета статті - здійснення комплексного аналізу змісту твору для висвітлення антиімперських ідей, втілених в історичній драмі. Метою передбачено виконання таких завдань: прочитання драматичного твору згідно 3 історичними та соціальними умовами життя нашого народу кінця XVII - початку XVIII століть; з'ясування ролі історичних і персоніфікованих образів героїв твору у формуванні антиколоніального супротиву.

Виклад основного матеріалу. «Милость Божія...» $є$ одним із видів шкільних історичних драм періоду бароко, для яких була характерною «розробка тем 3 історії інших народів, зокрема історії ізраїльського народу <...>» (Історія української літератури, 2014, Т. 2: 532). Звернення до фольклору (думи, історичні вірші та пісні про Б. Хмельницького) та козацьких літописів Самовидця і Г. Граб'янки урізноманітнило тематику, проблематику та зміст цього твору, що стало новизною для драматичних творів як жанру початку XVIII століття.

На думку дослідника давньої української драматургії М. Сулими, автор «Милості Божої...» при створенні драми все ж опирався на попередній драматичний досвід, однак він спромігся суттєво оновити жанрову структуру твору за рахунок мінімізації кількості алегорій і виведення головною дійовою особою українського гетьмана Б. Хмельницького (Історія української літератури, 2014, Т. 2: 534). Відтворюючи героїчну сторінку 
3 життя власного народу, а не чужоземного, невідомий автор поставив перед своїми сучасниками завдання продовжувати справу гетьмана - захищати рідну землю.

Відчуття більшого впливу народнопоетичної творчості, зокрема історичних пісень і віршів, у змісті драми «Милость Божія...», ніж у раніше представлених історичних драмах («Володимир» Феофана Прокоповича, «Іосиф Патріарха» Лаврентія Горки), вказує на перші промені преромантизму в національній літературі (культ народного духу, цінність незайманої національної поезіï). Така особливість історичного твору забезпечила драмі «Милость Божія...» «<...> чільне місце в давній українській драматургії» (Історія української літератури, 1967, Т. 1: 484).

У трьох перших діях драматичного твору невідомий автор, дотримуючись козацької літописної спадщини (літописи Самовидця і Г. Граб'янки) та жанру декламаційної п’сси (довгі монологи, колективні декламації та наявність хору), розробляє сюжет драми «Милость Божія...» відповідно до хронології подій Національно-Визвольної війни. Літописець - виходець із XVII століття (адже твір був репрезентований на сцені 1728 року) як син свого часу «<..> хоч незграбними, але гарячим українським патріотизмом пройнятими віршами» (Франко, 1984, Т. 41: 93) згадує перемоги армії Хмельницького навесні 1648 року у Жовтоводській і Корсунській битвах. Ці перемоги втілили в собі прагнення гетьмана до звільнення нашого народу від релігійних і соціальних утисків Речі Посполитої, що викривається у символічній назві твору - «Милость Божія...».

Милість Божа - це алегоричний образ звільнення 3 пекла різних грішників. У драмі місію звільнення грішних, тобто українців, покладено, як зазначає М. Сулима, на Б. Хмельницького, образ якого характеризується подвійністю. Специфіка його зображення, на думку П. Білоуса, полягає в реальному показі харизматичної історичної особи та ідеалізованого героя, якого наділено атрибутами святості (релігійність, якості Пророка і Вчителя) (Білоус, 2009: 332). Ім'я гетьмана «Богдан» тлумачиться як «Богом Даний», а його подвиг - «<..> як втілення Милості Божої» (Білоус, 2009: 332), що відповідає задуму автора.

Неосяжну радість перемоги над польським пануванням драматург вкладає у монологи алегоричних образів Дітей українських і Писаря, які 3'являються у четвертій дії драматичного твору. Така концепція відповідає вимогам бароко щодо алегорично-символічного плану зображення і дає змогу стверджувати, що вказані символічні образи уособлюють ставлення наших співвітчизників початку XVIII століття до подій НаціональноВизвольної війни. Діти українські - це збірний образ молодого покоління кінця XVII - початку XVIII століття, а образ Писаря - це козацька старшина 20-х років XVIII століття, яка поступово втрачає патріотичну свідомість. Молоде покоління (Діти українські) із захопленням і вдячністю прославляє гетьмана, консолідуючи зі славою величі предків, почутої ще від батьків: «Славою предковь твоихъ поощренъ, на рати / Побъдиль еси славно твоя супостаты <..>> (Милость Божія, 1858: 92).

Збірний образ зденаціоналізованої козацької старшини другої половини XVII століття (Писар) також висловлює свою похвалу гетьманові, акцентуючи увагу на тогочасному «віруванні» українців-малоросіян (назва Малоросія з'явилася у другій половині XVII століття) у заслуги Переяславської угоди, в основу якої лягло віросповідання «<..> Радуется о тебе [Богдане. - Ю. В.] Россія Малая, / Веселитжеся купно и Церковь Святая <..>» (Милость Божія, 1858: 93). Така позиція козацької старшини грунтувалася на факті одержання платні від імператорського уряду, що передбачалося Березневими статтями 1654 року, Переяславськими статтями 1659 року, Московськими статтями 1665 року та іншими міждержавними актами, укладеними між урядами Гетьманщини та Московської держави (Бойко, 2002). Формування «перевертнів» серед козацької верхівки було одним із основних завдань колоніальної політики царського уряду.

Разом із згадкою про колонізацію із вуст Писаря лунають вислови про давність українців, які за несприятливих історичних умов (міжусобна боротьба князів, нашестя монголо-татар) опинилися під польською експансією, з якої були визволені Б. Хмельницьким: «<..> якъ Вкраина стала, / Толикая въ ней радость еще не бувала» (Милость Божія, 1858: 93). Сам факт вживання назви «Вкраина» для нашої держави у репліці героя драми Писаря свідчить про спробу автора натякнути про високоосвіченість козацької старшини другої половини XVII століття, що суперечило уявленням московитів про українців як нерозумну та несвідому націю - «хохлів» (вираз з’явився у другій половині XVII століття).

Слова «Вкраина» або «Україна» вперше зустрічаємо в Іпатіївському списку Київського літопису 1187 року, що вказує на поширення грамотності та елементарної освіти в Україні у XVI - XVII століттях силами громадян (Бойко, 2002). Топонім «Вкраина» вкладено у вуста Писаря для роздвоєння його символічного образу на зденаціоналізо- 
вану та патріотично налаштовану козацьку старшину. Такою деталлю автор заявив, що на початку XVIII століття у рядах козаків були свідомі патріоти рідної держави, які протистояли своїм зденаціоналізованим співвітчизникам. Топонім «Вкраина» символізує сакральну назву окремого рідного краю прадавніх русів (Б. Грінченко, В. Русанівський, Г. Півторак, С. Єрмоленко), які навіки вкоренилася у козацьких землях їх нащадків - українців (крайовий топонім кінця XVI століття), набуваючи особливого значення у політичному та культурному житті Гетьманщини з початку XVII століття.

Вихід на сцену Писаря у четвертій дії драми як уособлення зденаціоналізованої козацької старшини провокує появу символічного образу гетьмана Б. Хмельницького. Споглядаючи за нищенням козацької автономії імперським урядом після Переяславської угоди (1654 року), автор п'єси звертається до своїх співвітчизників вустами гетьмана-визволителя 3 проханням не захоплюватися московськими підкупами для збереження цілісності держави. Заклик Б. Хмельницького до українців пізніше розкрив у своїх роздумах про наше козацтво Д. Донцов у словах: «Кожна сильна суспільність міцна твердим моральним законом, який над нею панує <...>» (Донцов, 2005: 151).

Поява гетьмана-переможця перед Золотими Воротами на початку четвертої дії драми набуває символічності. Золоті Ворота є символом сили і незалежності нашої держави. Як одна із найдавніших датованих споруд Східної Європи вони підкреслюють факт давності і могутності українців. Через ці ворота до міста мали приходити лише «благі вісті», оскільки князь Ярослав Мудрий, згідно 3 «Літописом руським», заложив на Золотих Воротах кам'яну церкву Благовіщення Пресвятої Богородиці, щоб «давати завше радість городу сьому святим Благовіщенням Господнім і молитвою святої Богородиці та архангела Гавриїла» (Літопис руський, 1989: 89).

Державницький світогляд мудрого керманича щільно переплітається 3 християнською ідеологією, що відповідає канонам барокового стилю (контрастність, парадоксальні поєднання, алегоричність і символізм). Застереження від спокусливої заздрості у бік ближнього, неправдивого збагачення, звернення до сусідів-московитів, відображене у рядках драми: «Не обидите ни чимъ братіи своея: / Кто льсокъ добрый, или хуторецъ порядный, / Кто став, кто луку, кто садъ имЂеть изрядный, / Больть или завђдеть тому не хотите, / Якъ бы его привлащить къ себы не ищите» (Милость Божія, 1858: 94). Слова-застереження, вміщені у зверненні гетьмана, відобра- зили колоніальну політику московського уряду на Україні після Переяславської угоди.

Заклик не забувати про зброю, а тримати іiі завжди напоготові лунає із вуст Хмельницького як заповідь для нашого народу, яка стала надзвичайно актуальною в боротьбі із зазіханнями Москви на панування в Козацькій Україні у другій половині XVII століття: «А жельзо доброе важте и надъ злато, / Злато бо потемнъетъ безъ него, якъ блато <...>. / Напосльдокъ глаголю: сами не купчуйте: / Лука, стрълки, мушкета и шабли пильнуйте!» (Милость Божія, 1858: 94).

Боротьба 3 московськими колонізаторами України у другій половині XVII - першій половині XVIII століття не сприймається як гріх. На думку M. Корпанюка, вона $є$ Божим праведним гнівом за глибокі та несправедливі соціальні й національні кривди, задані нашому народові (Корпанюк, 2005: 423-424). I. Франко зазначав, що після Полтавської битви (1709 рік) на Задніпрянщині відбувалася «інтенсивна акція російського уряду в напрямі обкроєння до мінімуму української автономії та людських свобод козацької людності $<\ldots>$..» (Франко, 1983, Т. 40: 321).

Автор «Милості Божої...» монологами гетьмана-визволителя України (етнічна назва фіксується у документах, пов'язаних із подіями Національно-Визвольної війни) підпорядковує ідейно-художній зміст декламаційної п'єси висвітленню антиколоніального супротиву 3 огляду на ліквідацію державних прав Гетьманату, зруйнування Батурина, створення Малоросійської колегії, заборону друку книг українською мовою та розправу над П. Полуботком. Образ Б. Хмельницького $є$ символом прагнення нашого народу до волі, до єдності в боротьбі з чужоземними загарбниками. Варто погодитися із влучною думкою С. Єфремова, що «всю драму прошито червоною ниткою козаколюбного настрою та українським патріотизмом < ...> (Сфремов, 1995: 118).

Завершальними акордами промови гетьмана перед киянами $є$ звернення до нащадків із закликом: «И дътей своихъ, скоро отправлять науки, / До сей же обучайте Козацкои штуки» (Милость Божія, 1858: 94). Актуальність висловленого гучно лунає за часів гетьманування Д. Апостола (1727-1734 роки), тобто в часи створення драми, коли, за слушним зауваженням П. Білоуса, активізувалася боротьба за скасування обмежень і утисків, яких зазнала українська культура від Петра I та його оточення (Білоус, 2009: 332).

П’ята дія п'єси «Милость Божія...» розкриває причину обрання теми твору (НаціональноВизвольна війна під проводом Б. Хмельницького), 
опираючись на основний пункт тогочасної автономної боротьби - змагання гетьмана Д. Апостола за дотримання Російською імперією Березневих статей 1654 року.

У монолозі Смотрђнія Божого звучить згадка про державну політику гетьмана Лівобережної України у 1727-1734 роках, яка «<..> храбрыми славна <..>» (Милость Божія, 1858: 97). Він, за зауваженням автора драми, має бути захисником України, а отже «<..> Хмельницькім твоимъ будетъ вторый <..>» (Милость Божія, 1858: 97). В. Шевчук підкреслює, що, на думку драматурга, Д. Апостол має стати другим Хмельницьким, тобто «<...> тим героєм, який постане за свободу, права й вольності» (Шевчук, 2005, Кн. 2: 486) свого народу.

У «Дневнику Петра Даниловича Апостола», надрукованого в журналі «Кіевская старина» (1895 рік) також знаходимо інформацію про патріотизм Д. Апостола, який «<...> принималь горячее участіе въ мечтаніяхъ Мазепы» (А. Л., 1895, № 7: 100). Прихильність гетьмана-мазепинця до поглядів I. Мазепи пізніше була продемонстрована приєднанням до протесту старшини, очоленого П. Полуботком, проти «<...> реформъ Петра В. [Петра I. - Ю. В.] въ Малороссіи < ...> (А. Л., 1895, № 7: 103). Отже, автор драми «Милость Божія ...» не даремно назвав Д. Апостола «другим Хмельницьким», знаючи про його антимосковські виступи на початку XVIII століття в рядах козацької старшини.

Персоніфікований образ Смотрьнія Божого відповідає задумові автора, адже означає не так слово «дивитися» як «піклуватися заздалегідь», що співзвучно із політичною опікою гетьмана Д. Апостола над своєю державою: «Но Богъ тя во воинскомъ искуствђ и штуці / Прославивый, прославитъ Тойже и въ науць. / И сіе Коллегіумъ чрезъ Петра Могилу / Основалъ, произведетъ въ толикую силу <...> (Милость Божія, 1858: 98). Варто погодитися із думкою М. Корпанюка, який зауважив, що створений образ Д. Апостола $є$ «<..> досить привабливий як розбудовника-державця» (Корпанюк, 2005: 633).

Згадка засновника Києво-Могилянської академії нагадує українцям про історію цього закладу, який почав відновлюватися від репресій Петра I, пов'язаних з опікою освітнім центром І. Мазепою, лише з обранням гетьманом Д. Апостола. Л. Алексієвець зазначив, що суспільно-політична роль Києво-Могилянської академії залежала від державно-правового статусу України протягом XVII XVIII століть в межах тих держав, до складу яких вона входила (Алексієвець, 2000: 19). Злодіяння імперського уряду щодо України, зокрема виси- лання козаків у воєнні «тяжкіе походы» (Милость Божія, 1858: 97) за межі власної держави, згадуються у монолозі Смотрьнія.

Слушною є думка дослідника давньої української літератури В. Шевчука, який зауважив, що «п'єсу витримано в офіційному дусі вірнопідданства російським монархам, але тільки в поверховому читанні <...> (Шевчук, 2005, Кн. 2: 485). Сила і велич російських царів порівнюється із каменем, що розглядається як міць $\mathrm{i}$ непорушність. Орієнтуючись на одну із основних барокових засад - релігійність, символ каменю варто ототожнювати із біблійним «каменем спотикання», який уособлює нездоланну перешкоду на шляху до досягнення якоїсь мети. Петро I, за уявленнями автора драматичного твору, і є тим «каменем спотикання» - перешкодою для українців, тобто «грішників», які не дотримуються «праведних законів» імперського уряду на шляху до своєї ідентичності та самобутності: «Петръ тебъ будеть камень, отъ Бога поданный, / И за величество дъль, Великій прозванный» (Милость Божія, 1858: 97). Поєднання барокових і християнських традицій в образі Петра I, представленого символічним каменем, дало змогу літописцеві відобразити антиколоніальний погляд українців XVIII століття на постать імператора як нездоланну перешкоду на своєму шляху.

Надія нашого народу на звільнення від колоніальної системи імперії після смерті Петра I (1725 рік) вдруге почала згасати. Незважаючи на свій юний вік (12 років), імператор Петро II (вступив на престол у 1727 році), перебуваючи під впливом лютого українофоба князя Олександра Меншикова, скасував петицію гетьмана Д. Апостола про повернення Гетьманщині прав, викладених ще в договірних статях Переяславської угоди (1654 року) Б. Хмельницьким, надавши «Рішительні пункти» (серпень 1728 року), які обмежили козацьке самоврядування (Політична історія України, 2008).

Скориставшись знаковою подією (80-річчя перемогивійськаБ. ХмельницькогоубитвіпідЖовтими Водами), автор «Милості Божої...» репрезентував осмислення українцями колоніальної політики Петра II щодо Козацької України. Молодого імператора представлено «другим каменем» імперії, співставлено ще з одним «каменем спотикання» для нашого народу в напрямку до антиколоніального супротиву: «Камень другій, не меньшій, будеть положенный, / Петръ, глаголю, имени Вторый такого <...> (Милость Божія, 1858: 97).

Значення дати 16 травня 1728 року в національній історії (80-річчя перемоги в НаціональноВизвольній війні) і час надання «Рішительних ста- 
тей» гетьману Д. Апостолу (22 серпня 1728 року) дають можливість стверджувати, що драма «Милость Божія....» була написана й оприлюднена невідомим автором у другій половині 1728 року після осмислення цих двох історичних подій. Незважаючи на те, що п’єса була поставлена лише один раз, вона зуміла підняти суспільно значущі проблеми колоніального становища нашої держави протягом майже 100 років, презентувавши «< .. > барокову декламаційну драму у кращих традиціях шкільного театру» (Білоус, 2009: 332-333).

Висновки. Історичний огляд подій від перемоги Б. Хмельницького у Національно-Визвольній війні до сучасного авторові періоду надання «Рішительних статей» гетьману Д. Апостолу та концентрація уваги на двох імператорах (Петро I та Петро II) допомогли драматургові відобразити регресивний політичний розвиток нашої держави, яка потроху перетворилася на колонію Російської імперії. Така особливість драми, за спостережен- ням В. Шевчука, слугувала закріпленню історичної пам'яті нашого народу і провела «виразні історичні паралелі» (Шевчук, 2005, Кн. 2: 485). Внесення реалістичної новизни у створення національної драматичної літератури у першій половині XVIII століття створило противагу сліпому наслідуванню єзуїтської драми, чим визволило ії «<..> з-під схоластичної шкаралущі» (Возняк, 1924: 230).

Проблемно-ідейний зміст твору, грунтуючись на двох сюжетних лініях (розкриття подій Національно-Визвольної війни і показ колоніального становища нашого народу у другій половині XVII - першій XVIII століть), які щільно переплітаються між собою, дав змогу правильно відобразити антиколоніальні настрої наших співвітчизників того часу, що дуже важливо для майбутніх поколінь українців у відстоюванні незалежності нашої держави та у сфері дослідження історії колоніального супротиву на теренах України.

\section{СПИСОК ВИКОРИСТАНИХ ДЖЕРЕЛ}

1. А. Л. Дневникъ Петра Даниловича Апостола. Киевская старина. Т. LI. № 7. Кіевъ, 1895. С. 100-155.

2. Алексієвець Л. М. Нові підходи у визначенні ролі Києво-Могилянської Академії в суспільному житті України (XVII - XVIII століття). Наукові записки НаУКМА. Том 18. Ювілейний випуск, присвячений 385-річчю КМА. 2000. C. 19-23.

3. Білоус П. В. Історія української літератури XI - XVIII ст. : навч. посіб. Київ : ВЦ «Академія», 2009. 424 с.

4. Бойко О. Д. Історія України : посібник. Київ : ВЦ «Академія», 2002. 656 с.

5. Возняк М. Історія української літератури. Том III: віки XVI - XVIII. Друга частина. Львів, 1924. 564 с.

6. Донцов Д. Де шукати наших історичних традицій. Дух нашої давнини. Київ : МАУП, 2005. 568 с.

7. Єфремов С. Історія українського письменства. Київ : Femina, 1995. 538 с.

8. Історія української літератури: У 8 т. Київ, 1967. Т. 1. 539 с.

9. Історія української літератури: У 12 т. Київ : Наукова думка, 2014. Т. 2. 840 с.

10. Книга пророка Ісаї. Біблія, або Книги Святого Письма Старого й Нового Заповіту / перек. I. Огієнко. Укр. біблій. товариство, 1988. С. 840-925.

11. Корпанюк М. Слово. Хрест. Шабля (Українське монастирсько-церковне, світське крайове літописання XVI XVIII ст., компіляції козацького літописання XVIII ст. як історико-літературне явище). Київ : Смолоскип, 2005.904 с.

12. Літопис руський / Пер. з давньорус. Л. С. Махновця; Відп. ред. О. В. Мишанич. Київ : Дніпро, 1989. 591 с.

13. «Милость Божія...». Чтенія въ Императорскомъ обществъ исторіи и древностей россійскихъ при Московскомъ университетr. Книга Первая. Москва, 1858. С. 75-100.

14. Політична історія України : посіб. / За ред. В. І. Танцюри. Київ : ВЦ «Академія», 2008. 552 с.

15. Франко І. Література другої половини 17 віку. Франко І. Зібрання творів: У 50 m. Київ : Наукова думка, 1983. T. 40. C. $308-322$.

16. Франко I. Українсько-руська (малоруська) література. Франко I. Зібрання творів: У 50 m. Київ : Наукова думка, 1984. Т. 41. С. 74-100.

17. Шевчук В. Муза Роксоланська: Українська література XVI - XVIII ст.: у 2 кн. Кн. 2. Київ : Либідь, 2005.728 с.

\section{REFERENCES}

1. A. L. Dnevnykъ Petra Danylovycha Apostola. [The diary by Peter Danilovich Apostle]. Kyiv antiquity. Kyiv, 1895. Volume LI. № 7. P. 100-155 [in Russian].

2. Aleksiievets L. M. Novi pidkhody u vyznachenni roli Kyievo-Mohylianskoi Akademii v suspilnomu zhytti Ukrainy (XVII - XVIII stolittia). [New approaches in determining the role of the Kyiv-Mohyla Academy in the public life of Ukraine (XVII - XVIII centuries)]. Scientific notes of NaUKMA, 18, 2000. P. 19-23 [in Ukrainian].

3. Bilous P. V. Istoriia ukrainskoi literatury XI - XVIII st. : navch. posib. [History of Ukrainian literature of XI - XVIII centuries : textbook]. Kyiv : VTs "Akademiia", 2009. 424 p. [in Ukrainian].

4. Boiko O. D. Istoriia Ukrainy : posibnyk. [History of Ukraine : textbook]. Kyiv : VTs "Akademiia”, 2002.656 p. [in Ukrainian].

5. Vozniak M. Istoriia ukrainskoi literatury. [History of Ukrainian literature]. Lviv, 1924. Volume III: viky XVI - XVIII. Druha chastyna. 564 p. [in Ukrainian]. 
6. Dontsov D. De shukaty nashykh istorychnykh tradytsii. Dukh nashoi davnyny. [Where do look our historical traditions. The spirit of our antiquity]. Kyiv : MAUP, 2005. 568 p. [in Ukrainian].

7. Yefremov S. Istoriia ukrainskoho pysmenstva. [History of Ukrainian literature]. Kyiv : Femina, 1995. 538 p. [in Ukrainian].

8. Istoriia ukrainskoi literatury. [History of Ukrainian literature]. Kyiv, 1867. Volume 1. 539 p. [in Ukrainian].

9. Istoriia ukrainskoi literatury. [History of Ukrainian literature]. Kyiv : Naukova dumka, 2014. Volume 2. 840 p. [in Ukrainian].

10. Ohiienko I. (Ed.). Knyha proroka Isai. [The book of the prophet Isaiah]. The Bible or the Scriptures of the Old and New Testaments, 1988. P. 840-925 [in Ukrainian].

11. Korpaniuk M. Slovo. Khrest. Shablia (Ukrainske monastyrsko-tserkovne, svitske kraiove litopysannia XVI - XVIII st., kompiliatsii kozatskoho litopysannia XVIII st. yak istoryko-literaturne yavyshche). [Word. Cross. Saber (Ukrainian monastery-church, secular regional chronicle of the XVI - XVIII centuries, compilations of the Cossack chronicle of the XVIII century as a historical and literary phenomenon)]. Kyiv : Smoloskyp, 2005. 904 p. [in Ukrainian].

12. Myshanych O. V. (Ed.); Makhnovets L. Ye. (Tr.). Litopys ruskyi. [Russian chronicle]. Kyiv : Dnipro, 1989. 591 p. [in Ukrainian].

13. "Mylost Bozhiia...". ["God's mercy..."]. Readings in the Imperial Society of Russian History and Antiquities at Moscow University. Moscow, 1858. Book 1. P. 75-100 [in Russian].

14. Tantsiury V. I. (Ed.). Politychna istoriia Ukrainy : posib. [Political history of Ukraine : textbook]. Kyiv : VTs "Akademiia", 2008. 552 p. [in Ukrainian].

15. Franko I. Literatura druhoi polovyny 17 viku. [Literature of the second half of the 17th century]. Collection of works: In 50 volumes. Kyiv : Naukova dumka, 1983. Volume 40. P. 308-322 [in Ukrainian].

16. Franko I. Ukrainsko-ruska (maloruska) literatura. [Ukrainian-Russian (Little Russian) literature]. Collection of works: In 50 volumes. Kyiv : Naukova dumka, 1984. Volume 41. P. 74-100 [in Ukrainian].

17. Shevchuk V. Muza Roksolanska: Ukrainska literatura XVI - XVIII st. [Muse Roksolanska: Ukrainian literature of the XVI - XVIII centuries]. Kyiv : Lybid, 2006. Book 2. 728 p. [in Ukrainian]. 